\title{
Hypertrophic osteopathy and bone metastases in a dog with prostatic carcinoma
}

\author{
Andréia Vielmo $^{1^{*}}$ (D) Ronaldo Michel Bianchi ${ }^{1}$ (D) Letícia Franciele Gomes Kinappe ${ }^{2}$ (D) \\ Cristiano Gomes ${ }^{2}$ Saulo Petinatti Pavarini ${ }^{1}$ (D)
}

${ }^{1}$ Setor de Patologia Veterinária, Faculdade de Veterinária, Universidade Federal do Rio Grande do Sul (UFRGS), 90040-060, Porto Alegre, RS, Brasil. E-mail: andreiavielmo@yahoo.com.br. "Corresponding author.

${ }^{2}$ Departamento de Medicina Animal, Faculdade de Veterinária, Universidade Federal do Rio Grande do Sul (UFRGS), Porto Alegre, RS, Brasil.

ABSTRACT: Prostatic carcinomas in are aggressive neoplasms and bone metastases may occur; however, hypertrophic osteopathy associated with that condition is poorly documented. A ten-year-old, neutered male, mixed breed dog had a history of lameness and volume increase in the left pelvic limb. On radiographic examination, a lytic bone mass was observed in the left metatarsus, as well as a diffuse proliferative periosteal reaction in several bones of the appendicular skeleton, in addition to radiopaque nodular structures in all lung lobes. A presumptive diagnosis of primary bone neoplasia with pulmonary metastases and hypertrophic osteopathy was established and chemotherapy treatment was started. However, there was no satisfactory clinical response, and euthanasia was ellected. At necropsy, there was moderate enlargement of the prostate gland. The gland was firm and whitish, with a multilobulated aspect. Several similar masses were observed in the right kidney, lungs, mediastinal lymph nodes, and multiple bones of the appendicular skeleton. These bones also presented evident diffuse periosteal reaction. Histological examination revealed a metastatic prostatic carcinoma with bone involvement and hypertrophic osteopathy. This report is an unusual case of metastatic prostatic carcinoma in association with hypertrophic osteopathy and concomitant bone metastases.

Key words: dog diseases, neoplasia, prostate, pathology.

Osteopatia hipertrófica e metástases ósseas em um canino com carcinoma prostático

RESUMO: Os carcinomas prostáticos em cães são neoplasmas agressivos e as metástases ósseas podem ocorrer, entretanto a associação com osteopatia hipertrófica é pouco relatada. Um canino, macho, sem raça definida de 10 anos de idade, com histórico de claudicação e aumento de volume em membro pélvico esquerdo, apresentou no exame radiográfico uma massa óssea, lítica em metatarso esquerdo, bem como reação periosteal proliferativa difusa em diversos ossos do esqueleto apendicular além de estruturas nodulares, radiopacas em todos os lobos pulmonares. Realizou-se o diagnóstico presuntivo de neoplasia óssea primaria com metástases pulmonares e osteopatia hipertrófica e iniciou-se o tratamento quimioterápico. Todavia, não houve resposta clínica satisfatória, optando-se pela eutanásia. Na necropsia foi constatado aumento de volume moderado da próstata, com aspecto multilobulado, ao corte firme e brancacento. Diversas massas similares foram observadas no rim direito, pulmões, linfonodos mediastínicos e em vários ossos do esqueleto apendicular, além de evidente reação periosteal difusa. A avaliação histológica revelou um carcinoma prostático metastático com envolvimento ósseo, bem como osteopatia hipertrófica pulmonar. Esse relato é um caso incomum de carcinoma prostático metastático devido a associação com osteopatia hipertrófica pulmonar e as metástases ósseas concomitantes.

Palavras-chave: doenças de cães, neoplasia, próstata, patologia.

Prostatic tumors are among the three main cancers in men (SIEGELet al., 2018). Dogs are the only mammals other than humans that have a significant frequency of prostate cancer (CHRISTENSEN, 2018). These two species present anatomical similarities in the prostate gland, and for this reason, dogs are used as a study model for this type of neoplasia (LEROY \& NORTHRUP, 2009). In dogs, prostatic neoplasms tend to be more aggressive and metastatic (BRYAN et al., 2007; LEROY \& NORTHRUP, 2009; CHRISTENSEN, 2018), and the most frequent sites of metastases are the lymph nodes, lungs, and bones (CORNELL et al., 2000). Pulmonary metastases, as well as masses or inflammatory processes in the thoracic cavity, can cause hypertrophic osteopathy, a syndrome characterized by diffuse periosteal bone 
neoformation along the diaphyses and metaphyses, mainly in limb bones (CRAIG et al., 2016). The association of prostatic tumors with pulmonary and bone metastases has been reported (JOHNSTON et al., 2000); however, the association with hypertrophic osteopathy is poorly reported (JENNINGS \& WATTS, 2018). Thus, the aim of this study was to describe the clinical and pathological findings of a metastatic prostatic carcinoma with bone involvement in a dog with hypertrophic osteopathy.

A ten-year-old, neutered male, mixed breed dog was presented for clinical examination with a history of lameness and volume increase in the left pelvic limb with evolution over two months. According to the owner, the dog had previously been diagnosed with osteomyelitis and was being treated with clindamycin (150 mg - BID for one month) and tramadol (100 mg - BID). There was mild clinical improvement. On physical examination, skin lesions (wet eczema) were observed in the pelvic limbs, in addition to lameness and distal enlargement of the left pelvic limb. An increase in alkaline phosphatase levels (189 IU/L; reference value $<156 \mathrm{IU} / \mathrm{L})$ was observed in the biochemical examination.

A radiographic examination revealed focal bone lysis in the distal metaphysis of the third metatarsal (Figure 1A); nodular area of soft tissue enlargement; presence of proliferative periosteal reaction in the diaphysis of the third metatarsal; epiphysis and medial diaphysis of the second metatarsal, caudal portion of the fourth tarsal bone, and calcaneus medial face. Diffuse proliferative periosteal reaction was also identified in several other bones, such as the femur, tibia, fibula, and tarsus. On thoracic radiographic examination, an interstitial pattern, with nodular radiopaque structures of varying sizes, was observed in all pulmonary lobes. Prostate had dimensions, shape, and echogenicity preserved in the ultrasound examination. These alterations were suggestive of primary bone neoplasia (osteosarcoma) with pulmonary metastasis and hypertrophic osteopathy. Due to the presence of pulmonary metastases in the radiographic examination and the unfavorable prognosis, a biopsy as well as limb amputation were not performed, and treatment was started with tramadol (100 mg - TID), dipyrone (25 mg/kg - TID), firocoxib (5 mg/kg - SID) and pamidronate $(1 \mathrm{mg} / \mathrm{kg}$ diluted with $0,9 \%$ sodium chloride to a total volume of $250 \mathrm{ml}$ ). An initially improvement of the clinical condition was observed, and the use of carboplatin $\left(300 \mathrm{mg} / \mathrm{m}^{2}\right.$ every 21 days for 4 cycles) was established. However, two months later the dog presented lateral decubitus, vomiting, lethargy, and anorexia. The left pelvic limb showed a marked swelling and, according to the tutor, the animal showed severe lameness. Owing to the poor prognosis, the owner opted for euthanasia.

Grossly, the prostate was moderately enlarged, irregular, white, and multilobulated. In all pulmonary lobes, multiple, firm, umbilicated, and white nodules ranging from 0.2 to $2.0 \mathrm{~cm}$ in diameter were observed (Figure 1B). The mediastinal lymph nodes were markedly enlarged, firm, with a white and multilobulated cut surface interspersed with small cystic structures. In the right kidney, a white and firm mass of $4.0 \times 3.0 \times 2.0 \mathrm{~cm}$ was observed, besides purulent brownish content in the pelvis (pyelonephritis). In the distal part of the left metatarsal bone and extending to the first phalange, a mass of 8.0 x $4.0 \times 4.0 \mathrm{~cm}$ was observed (Figure 1C). At the cut surface, the mass was firm, reddish, interspersed with white areas, which destroyed the bone tissue. Multifocal proliferation of reddish tissue on the periosteal surface ( 1 to $4 \mathrm{~cm}$ in diameter), similar to that described in the left pelvic limb, was also observed in several bones (humerus, radius, ulna, fibula, and scapulae). All these bones also presented irregular and tortuous surface, sometimes associated with moderate and diffuse periosteal proliferation (Figure 1D). Multiple ulcerations of the gastric mucosa as well as digested blood inside the intestine were also observed. Fragments of different tissues were collected, fixed in $10 \%$ buffered formalin, routinely processed, and stained with hematoxylin and eosin.

Histologically, the prostate showed a malignant proliferation of neoplasic epithelial cells, which involved the prostatic urethra. Neoplastic cells were arranged in lobes, surrounded by a moderate amount of stroma, with a predominantly cribriform arrangement (Figure 1E). These cells were polygonal, with a low nuclei/cytoplasmic ratio. The cytoplasm was abundant, eosinophilic, and often had large vacuoles that displaced the nuclei to the periphery of the cell. These vacuoles were empty or contained small eosinophilic concretions (Melamed-Wolinska bodies - Figure 1E inset). Nuclei were vesicular and varied from round to oval, with evident and multiple nucleoli. Marked anisocytosis and anisokaryosis, macrokaryosis, occasional multinucleated cells, and an average of three mitotic figures per higher power magnification (400x) were observed. Neoplastic cells were also noted within prostatic blood and lymphatic vessels. Based on the histological aspect, the neoplasm was classified as cribriform prostatic urothelial carcinoma (PALMIERI et al., 2019). Neoplastic epithelial cells identical to those observed 


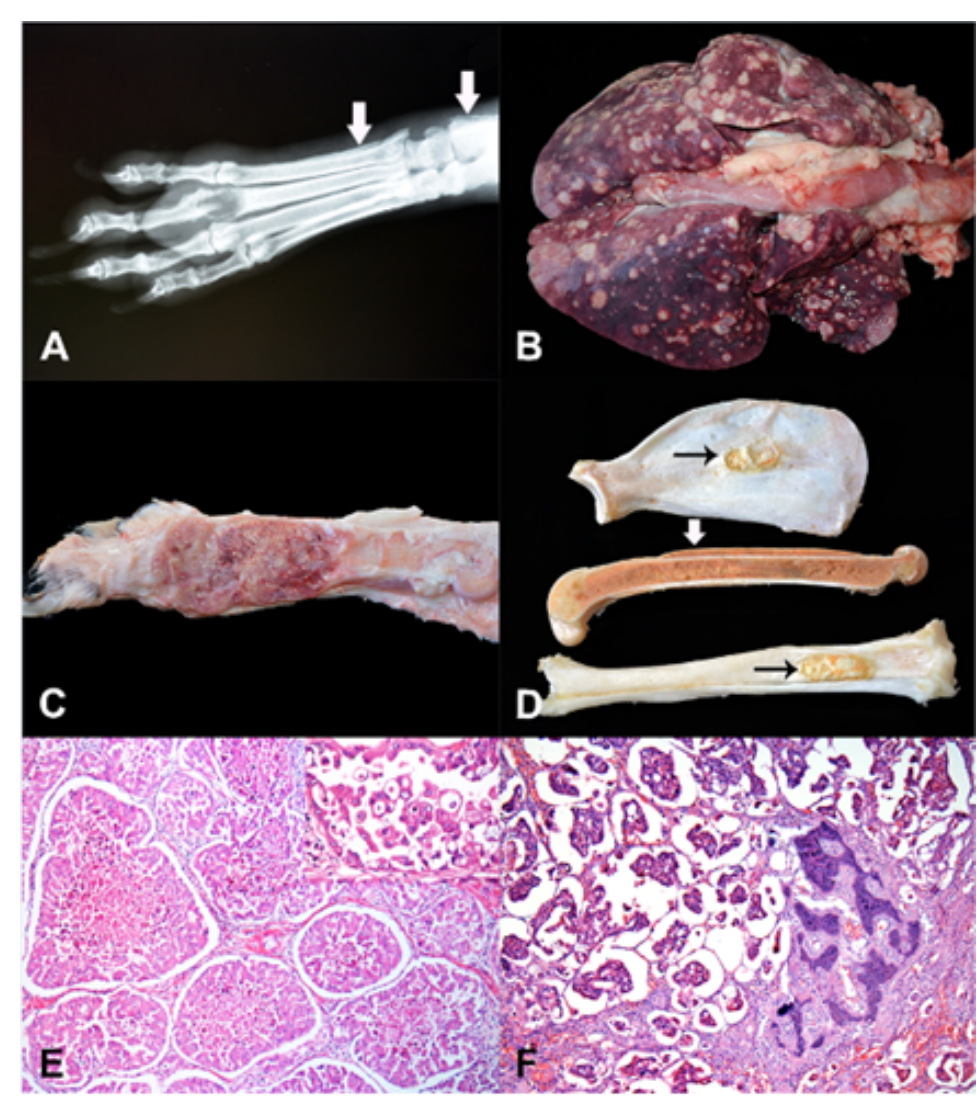

Figure 1 - Metastatic prostatic carcinoma resembling an osteosarcoma in a dog with hypertrophic osteopathy. (A) Left pelvic limb - radiographic examination showing focal area of bone lysis in the distal metaphysis of the third metatarsal, nodular area of soft tissue enlargement and periosteal proliferative reaction on the cortical surface (arrow). (B) Lung - Multifocal, white, umbilicated, and firm nodules, ranging from 0.2 to $2.0 \mathrm{~cm}$ in diameter, are observed in all pulmonary lobes. (C) Left pelvic limb - a mass with a firm and reddish surface, interspersed with white areas is observed in the metatarsus and first phalanges. (D) Bones - Irregular and tortuous bones with a proliferation on the periosteal surface (arrow) and tumor masses (thin arrow). (E) Prostate - there is a malignant neoplastic proliferation of epithelial cells, which were arranged in lobes surrounded by a moderate amount of stroma, with a predominantly cribriform arrangement. Hematoxylin and eosin (HE), 200x. Inset: neoplastic cells with Melamed-Wolinska bodies. HE, 400x. (F) Left pelvic limb - There is replacement of the bone tissue by neoplastic cells. similar to that described in E. HE, 100x.

in the prostate were also observed in the bones, lungs, right kidney, and mediastinal lymph nodes and thus interpreted as metastases. In the left pelvic limb, there was destruction and replacement of a large part of the bone tissue by neoplastic proliferation, with extension to the subcutaneous and adjacent musculature (Figure $1 \mathrm{~F})$. In the other bones (humerus, radius, ulna, tibias, fibulae, and scapulae), nodular areas constituted by similar neoplastic cells were evident, as well as on the surface of the periosteum there was a marked proliferation of well differentiated bone tissue with presence of bone marrow. Other organs did not present significant histological lesions.

The diagnosis of metastatic prostatic carcinoma with bone involvement and hypertrophic osteopathy was based on clinical and pathological 
findings. In veterinary medicine, the canine species is the most affected by prostate tumors, which commonly present aggressive behavior and have a high propensity to metastasize (CORNELL et al., 2000). The risk of castration for prostatic neoplasms is not completely clear yet (SCHRANK \& ROMAGNOLI, 2020), but some authors believe that castrated dogs, as the dog in this case, have a higher risk of developing prostate cancer than dogs that are not neutered (TESKE et al., 2002; BRYAN et al., 2007). It is believed that the removal of androgens can create selection pressures that favor the progression of prostatic tumors to an aggressive state, raising the hypothesis that this tumor is androgen independent (CORNELL et al., 2000; BRYAN et al., 2007). These findings are consistent with a study that shows that most canine prostate cancers are of urothelial/ductal origin, which is independent of hormones (SORENMO et al., 2003). Besides that, the loss of androgen stimulation and the increase of estrogen in the prostatic tissue may be an important factor in the transformation of neoplasia (BRYAN et al., 2007). Estrogen is able, directly or indirectly, to induce COX-2 expression in the prostate. Overexpression of this enzyme has been demonstrated in prostate tissues with cancer, which leads to the potential association of this enzyme with carcinogenesis (SORENMO et al., 2004; DORÉ et al., 2005).

The metastases of prostatic carcinomas are usually observed in dogs with an average age of 10 years, and may occur in the bones leading to lameness, in a similar manner to that described in this case (COOLEY \& WATERS, 1998; CORNELL et al., 2000). When prostatic carcinomas metastasize to the appendicular skeleton, usually the femur is the most affected bone and only $5 \%$ of the skeletal lesions are distal to the knee or elbow (CORNELL et al., 2000). In contrast to what is often reported in the literature, the first site of canine bone metastasis in the present report occurred in the metatarsal and phalanx, and later it was possible to observe through necropsy examination that the metastases had also affected other bones of the appendicular skeleton.

Dogs with bone metastases are considered a challenge for the clinician that finds a bone lesion without a previous diagnosis of tumor. Sometimes, skeletal metastases are the first clinical manifestation of carcinomas (COOLEY \& WATERS, 1998; CORNELL et al., 2000), as observed in the present report, since locomotor alterations were the first manifestations in this case. Initially, the presumptive clinical diagnosis was osteosarcoma, because the dog had a lytic nodular bone lesion, as well as an increase in alkaline phosphate, which is considered a prognostic factor and commonly associated with primary bone tumors (BOERMAN et al., 2012). Although, these changes are suggestive of primary bone neoplasms, the definitive diagnosis of osteosarcoma should be made through histopathological analysis (CRAIG et al., 2016). Despite being extremely important for the definitive diagnosis, in the present report, the histopathological analysis was not performed due to the unfavorable prognosis of the dog, since pulmonary metastases had already been found by radiographic examination and it was decided not to perform a surgical procedure.

Pulmonary metastases can lead to hypertrophic osteopathy and, in response, nonedematous soft tissue swellings and a new diffuse periosteal reaction develop in all four limbs. The lesions are usually bilateral, symmetrical, and restricted to the limbs, and more severe in the distal bones. The most common clinical sign, in these cases, is mild to severe lameness (CETINKAYA et al., 2011; TROST et al., 2012, WHITERS et al., 2015), which may have exacerbated the lameness of this dog. Elevation of serum alkaline phosphatase levels that was observed in the dog of this report, is also reported in dogs with hipertrophyc osteophaty and is presumably due to enhance osteoblast activity as part of the $\mathrm{HO}$ progression, but may also have been secondary to bone metastases (WHITERS et al., 2015).

Results obtained in this report allow us to infer that; although, the sites affected by metastasis of prostatic carcinomas are frequently described, this report is an unusual case because of the association with hypertrophic osteopathy. In addition, the authors emphasized the possibility of bone involvement in cases of canine prostatic neoplasms and therefore, should be considered as an important differential diagnosis when tumor bone lesions are reported.

\section{ACKNOWLEDGEMENTS}

To the Conselho Nacional de Desenvolvimento Científico e Tecnológico (CNPq), and Coordenação de Aperfeiçoamento de Pessoal de Nível Superior (CAPES) for the financial support.

\section{DECLARATION OF CONFLICT OF INTERESTS}

The authors declare no conflict of interest. The founding sponsors had no role in the design of the study; in the collection, analyses, or interpretation of data; in the writing of the manuscript, and in the decision to publish the results.

\section{AUTHORS' CONTRIBUTIONS}

The authors contributed equally to the manuscript. 


\section{REFERENCES}

BOERMAN, I. et al. Prognostic factors in canine appendicularosteosarcoma-a meta-analysis BMC Veterinary Research, v.8, p.1-12 , 2012. Available from: $<$ https://bmcvetres biomedcentral.com/track/pdf/10.1186/1746-6148-8-56>. Accessed: Mar. 3, 2020. doi: 10.1186/1746-6148-8-56.

BRYAN, J. N. et al. A population study of neutering status as a risk factor for canine prostate cancer. The Prostate, v.67, p.1174-1181, 2007. Available from: <https://www.ncbi.nlm.nih. gov/pubmed/17516571>. Accessed: Sep. 1, 2019. doi: 10.1002 pros. 20590 .

CETINKAYA, M. A. et al. Hypertrophic osteopathy in a dog associated with intra-thoracic lesion: a case report and a review. Veterinarni Medicina, v.56, p.595-601, 2011. Available from: $<$ http://vri.cz/docs/vetmed/56-12-595.pdf>. Accessed: Sep. 1, 2019.

CHRISTENSEN, B. W. Canine Prostate Disease. Veterinary Clinics of North America: Small Animal Practice, v.48, p.701719, 2018. Available from: <https:/www.ncbi.nlm.nih.gov/ pubmed/29933768>. Accessed: Sep. 1, 2019. doi: 10.1016/j. cvsm.2018.02.012.

COOLEY, D. M.; WATERS, D. J. Skeletal metastasis as the initial clinical manifestation of metastatic carcinoma in 19 dogs. Journal of Veterinary Intern Medicine, v.12, p.288-293, 1998. Available from: $<$ https://www.ncbi.nlm.nih.gov/pubmed/9686389>. Accessed: Sep. 1, 2019. doi: 10.1111/j.1939-1676.1998.tb02124.x.

CORNELL, K. K. et al. Clinical and pathologic aspects of spontaneous canine prostate carcinoma: a retrospective analysis of 76 cases. The Prostate, v.45, p.173-183, 2000. Available from: $<$ https://www.ncbi.nlm.nih.gov/pubmed/11027417>. Accessed: Sep. 1, 2019. doi: 10.1002/1097-0045(20001001)45:2<173::aidpros $12>3.0 . c 0 ; 2-$.r.

CRAIG, L. E. et al. Bones and joints. In: JUBB; KENNEDY; PALMER'S. Pathology of Domestic Animals. St. Louis: Elsevier, 2016, V.1, Cap.2, pp.17-163.

DORÉ, M. et al. Estrogen-dependent induction of Cyclooxygenase-2 in the canine prostate in vivo. Veterinary Pathology, v.42, p.100-103, 2005. Available from: <https://www. ncbi.nlm.nih.gov/pubmed/15657282>. Accessed: Sep. 1, 2019. doi: 10.1354/vp.42-1-100.

JENNINGS, K.; WATTS, J. Hypertrophic osteopathy in a castrated dog with prostatic carcinoma and prostatitis. Journal of Small Animal Practice, v.59, p.719, 2018. Available from: $<$ https://www. ncbi.nlm.nih.gov/pubmed/30168146>. Accessed: Sep. 1, 2019. doi: 10.1111/jsap. 12919 .
JOHNSTON, S. D. et al. Prostatic disorders in the dog. Animal Reproduction Science, v.60-61, p.405-415, 2000. Available from: $<$ https://www.ncbi.nlm.nih.gov/pubmed/10844211>. Accessed: Sep. 1, 2019. doi: 10.1016/s0378-4320(00)00101-9.

LEROY, B. E.; NORTHRUP, N. Prostate cancer in dogs: comparative and clinical aspects. The Veterinary Journal, v.180, p.149-162, 2009. Available from: <https://www.ncbi.nlm.nih. gov/pubmed/18786842>. Accessed: Sep. 1, 2019. doi: 10.1016/j. tvj1.2008.07.012.

PALMIERI, C. et al. Histopathological terminology standards for the reporting of prostatic epithelial lesions in dogs. Journal of Comparative Pathology, v.171, p.30-37, 2019. Available from: <https://www.sciencedirect.com/science/ article/pii/S0021997519301537>. Accessed: Mar. 3, 2020. doi: 10.1016/j.jcpa.2019.07.005.

SIEGEL, R. L. et al. Cancer Statistics, 2018. CA: A Cancer Journal for Clinicians, v.68, p.7-30, 2018. Available from: <https://www. ncbi.nlm.nih.gov/pubmed/29313949>. Accessed: Sep. 1, 2019. doi: 10.3322/caac. 21442 .

SORENMO, K. U. et al. Immunohistochemical characterization of canine prostatic carcinoma and correlation with castration status and castration time. Veterinary and Comparative Oncology, v.1, p.48-56, 2003. Available from: <https://www.ncbi.nlm.nih.gov/ pubmed/19379330>. Accessed: Mar. 3, 2020. doi: 10.1046/j.14765829.2003.00007.x.

SORENMO, K. U. et al. Evaluation of cyclooxygenase-1 and cyclooxygenase- 2 expression and the effect of cyclooxygenase inhibitors in canine prostatic carcinoma. Veterinary and Comparative Oncology, v.2, p.13-23, 2004. Available from: $<$ https:/www.ncbi.nlm.nih.gov/pubmed/19379307>. Accessed: Mar. 3, 2020. doi: 10.1111/j.1476-5810.2004.00035.x.

TESK, E. et al. Canine prostate carcinoma: epidemiological evidence of an increased risk in castrated dogs. Molecular and Cellular Endocrinology, v.197, p.251-255, 2002. Available from: $<$ https://www.ncbi.nlm.nih.gov/pubmed/12431819>. Accessed: Mar. 3, 2020. doi: 10.1016/s0303-7207(02)00261-7.

TROST, M. E. et al. Osteopatia hipertrófica em sete cães. Pesquisa Veterinária Brasileira, v.32, p.424-429, 2012. Available from: $<$ http://www.scielo.br/scielo.php?script $=$ sci_arttext\&pid $=$ S0100736X2012000500011>. Accessed: Sep. 1, 2019. doi: 10.1590/ S0100-736X2012000500011.

WHITERS, S. S. et al. Paraneoplastic hypertrophic osteopathy in 30 dogs. Veterinary and Comparative Oncolology, v.13, p.157-165, 2015. Available from: <https://www.ncbi.nlm.nih.gov/pmc/articles/ PMC5012418/>. Accessed: Mar. 3, 2020. doi: 10.1111/vco.12026. 